\title{
The influence of different agrochemicals foliar sprays on postharvest fruit quality of Navel orange
}

\author{
H. A. Kassem ${ }^{1 *}$, H. A. Marzouk ${ }^{2}$, A. EL-Kobbia ${ }^{2}$ M. Abo-Elmagd ${ }^{2}$ \\ ${ }^{1}$ Plant production Department, Faculty of Food and Agricultural Sciences, King Saud University, \\ Kingdom of Saudi Arabia; ${ }^{2}$ Pomology Department, Faculty of Agriculture (El-Shatby), \\ Alexandria University, Alexandria, Egypt
}

\begin{abstract}
The present investigation was carried out during the two successive growing seasons of 2003 and 2004 on Washington Navel orange trees grown at El-Tarh region, El-Behera Governorate, in order to study the effect of spraying orange trees with different agrochemicals on fruit quality. For the present study, 96 trees were selected as uniform as possible and divided into two groups. The first group was subjected to the foliage treatments when the fruit reached pea size $(5 \mathrm{~mm}$ in diameter) and the second at marble size ( $15 \mathrm{~mm}$ in diameter). Fruit weight was significantly increased in both seasons by spraying 2,4$\mathrm{D}+$ boric acid at the pea or marble stages. In addition, spraying 2,4-D + boric acid at the marble stage only increased fruit length .Vitamin $\mathrm{C}$ content was not affected by all sprays at the pea stage, whereas it was significantly increased in the first season by spraying 2,4-D, 2,4-D + calcium chloride, 2,4-D+ calcium acetate, urea or boric acid alone at the marble stage. In the second season, fruit acidity was increased by spraying boric acid at both pea and marble stage, whereas, it was decreased by spraying 2,4-D + calcium chloride ( pea stage) and 2,4-D + boric acid (marble stage). Spraying 2,4-D + calcium super phosphate at pea or marble stage significantly increased TSS percent. In addition, all treatments enhanced fruit color in both pea and marble stages over the control, especially, treatments that included foliar spray of 2,4-D. In general, most 2,4-D sprays combined with other compounds had significant influence on fruit quality characteristics.
\end{abstract}

Keywords: Navel orange, agrochemicals, fruit quality, postharvest, foliar sprays.

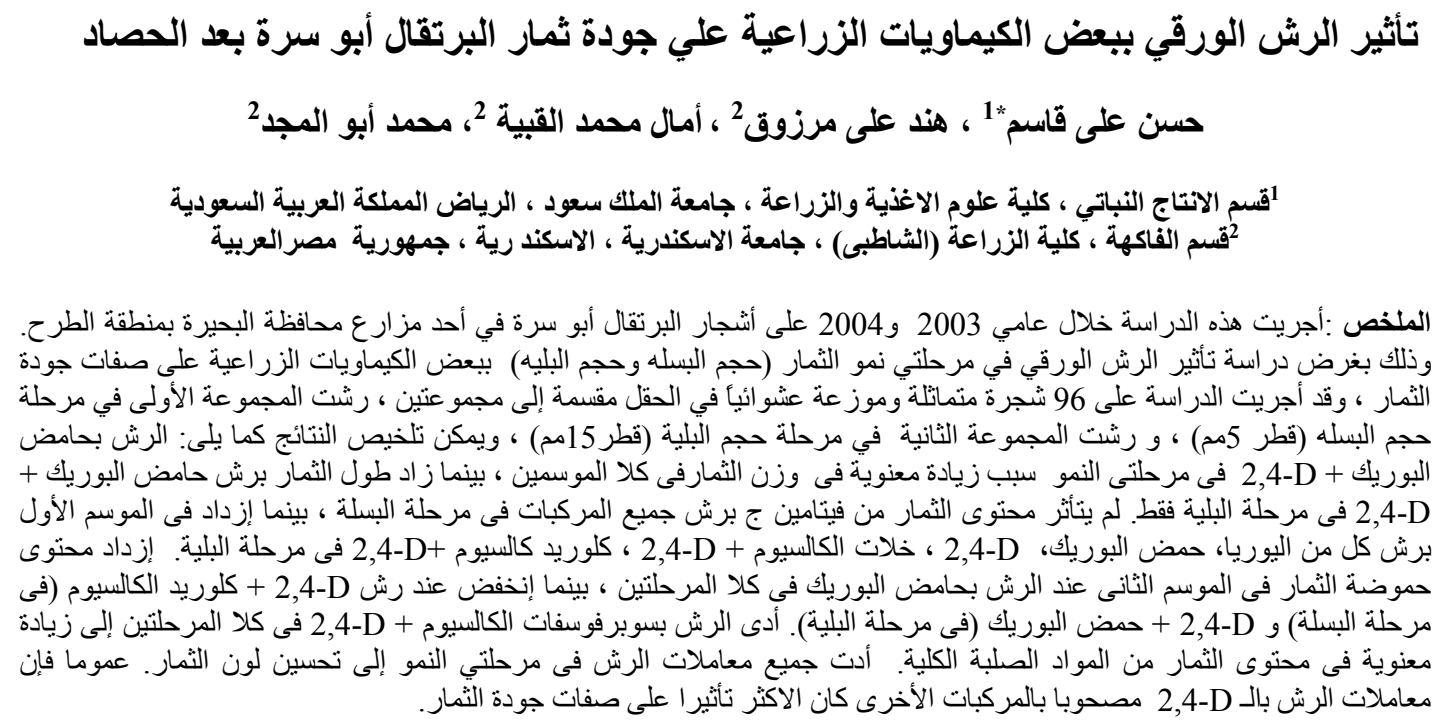

* Corresponding Author, Email: kassem60@yahoo.com 


\section{Introduction}

Citrus in Egypt is a major export product. Egypt has the potential to export close to one million tons of fresh fruits by the year 2010 (Hofer, 2006). Today, Egypt stands at the tenth and fourth position among the top citrus producing and exporting countries, respectively (F.A.O., 2010). In Egypt Washington Navel orange is the most important and popular orange variety that is consumed and exported as fresh fruit. Recently, the production of high quality citrus crop for export purposes is highly awarded specially by Navel orange growers. Fruit siz represents one of the most important quality characteristics for citrus fresh consumption (Agusti et al., 2002) as well as external features like fruit colour, size, and peel texture are the important parameters to estimate the quality of the fruit, while internal characters contributing to fruit quality include amount and quality of juice, seediness, vitamin $\mathrm{C}$ contents, total soluble solids (TSS), titratable acidity (TA) and TSS: TA ratio. (Ahmed, 2006). Improving citrus fruit quality can be achieved by several steps including; high quality nurseries, good agricultural practices and standardized citrus packing stations. The major agricultural practice that affects tree nutritional status and has strong impact on its fruit quality characteristics is fertilization. Both macro and micro- nutrients such as $\mathrm{N}, \mathrm{Ca}$ and Bo are critical nutrients for fruit growth and quality (Shoeib and El-Sayed, 2003). Urea was reported to enhance fruit size, peel thickness and juice (El-Otmani, 2002). Its application as foliar sprays is reported to be absorbed rapidly and efficiently by leaves of most fruit crops (Johnson et al., 2001) and are commonly sprayed in citrus plantation without causing any phytotoxic effects (Alberigo, 2002). Also, foliar sprays of calcium, boron and zinc either alone or in combinations, have been shown to protect the plant against stress (Andrews, 2002). Stress (i.e. high temperature stress) disrupt tree metabolism and causes physiological damage .However, date and number of applications must be considered according to the purpose aimed to obtain best result. Also, 2,4-D is a synthetic auxin which is known to be effective in enhancing Navel orange fruit quality such as weight and size (Ahmed, 2006 and Modise et al., 2009). It has been widely used as herbicide for several decades due to its relative moderate toxicity and biodegradability in plant and soil (National Research Council Canada, 1991 and Sterling and Hall, 1997). The world health organization (WHO) does not regard 2,4-D and its salts and esters as either genotoxic or carcinogenic, and established an acceptable daily intake (ADI) for 2,4-D of 0 to $0.01 \mathrm{mg}$ $/ \mathrm{kg} /$ day (USDA, 2006) which is far less from the concentration applied when it is sprayed as synthetic auxin on fruit trees.

From the previous above, the present study was carried out in order to investigate the influence of different agrochemicals foliar sprays either alone or in combinations to Washington Navel orange trees during two growing stages of the fruit (at pea and marble stages) on the different postharvest fruit quality characteristics.

\section{Material and methods}

\section{Plant material and treatments}

The effect of spraying Washington Navel orange trees with different agrochemicals on postharvest fruit quality was studied during 2003 and 2004 growing seasons. The present study was conducted in a private citrus orchard at El-Tarh region, EL- Behera Governorate. The soil was clay, well-drained with water table about $120 \mathrm{~cm}$ and $\mathrm{pH} 8$. Twenty years old Washington Navel orange trees (Citrus sinensis L.), budded on sour orange rootstock were planted at $4 \times 4 \mathrm{~m}$ apart and subjected to the same cultural practices usually done in the orchard.

In January of both seasons, calcium superphosphate $\left(15.5 \% \mathrm{P}_{2} \mathrm{O}_{5}\right)$ was added at the rate of $500 \mathrm{~kg}$ per feddan. Ammonium nitrate $(33 \% \mathrm{~N})$ was applied at the rate of $300 \mathrm{~kg}$ in March, $250 \mathrm{~kg}$ in May and $300 \mathrm{~kg}$ in August of both seasons per feddan. In August of both seasons, $100 \mathrm{~kg}$ per feddan potassium sulfate $\left(48 \% \mathrm{~K}_{2} \mathrm{O}_{5}\right)$ was added. Trees were irrigated with Nile water every 15-20 days. 
Ninety six trees were selected as uniform as possible and divided into two groups. The first group was subjected to the foliage treatments at the beginning of May when the fruit reached pea size $(5 \mathrm{~mm}$ in diameter), and the second at the end of May when the fruit reached marble size (15 $\mathrm{mm}$ in diameter). Trees were sprayed with, calcium chloride $(0.5 \%)$, calcium acetate $(0.5 \%)$, boric acid (150 ppm), urea (2\%), calcium superphosphate $(2 \%)$ and 2,4-D (20 ppm). 2, 4-D was sprayed alone or in combination with the previous mentioned compounds.

Treatments were arranged in a complete randomized design with four replicates for each treatment and trees of both groups were treated with the following 12 foliage treatments (i.e., 4 x $12=48$ trees/group):

$\mathrm{T} 1=$ Water spray only (control).

$\mathrm{T} 2=$ Calcium chloride $(0.5 \%)$.

$\mathrm{T} 3=$ Calcium acetate $(0.5 \%)$.

$\mathrm{T} 4=$ Boric acid $(150 \mathrm{ppm})$.

T5=Urea $(2 \%)$.

T6= Calcium superphosphate $(2 \%)$.

$\mathrm{T} 7=2,4-\mathrm{D}(20 \mathrm{ppm})$.

$\mathrm{T} 8=2,4-\mathrm{D}(20 \mathrm{ppm})+$ calcium chloride $(0.5 \%)$.

$\mathrm{T} 9=2,4-\mathrm{D}(20 \mathrm{ppm})+$ calcium acetate $(0.5 \%)$.

$\mathrm{T} 10=2,4-\mathrm{D}(20 \mathrm{ppm})+$ boric acid $(150$ ppm).

$\mathrm{T} 1=2$, 4-D (20ppm) + urea (2\%).

$\mathrm{T} 12=2,4-\mathrm{D}(20 \mathrm{ppm})+$ calcium superphosphate $(2 \%)$.

The surfactant Nourfilm (produced by Alam Chemca) at the rate of $40 \mathrm{~cm} / 100 \mathrm{~L}$ water was added to all sprayed chemicals in order to obtain best results.

\section{Fruit sampling}

At harvest date (mid - December), 25 fruit were sampled per replication uniformly from all sides of each tree of both groups in both growing seasons for physico-chemical analysis.

\section{Fruit physical analysis}

The fruits were washed under tap water, dried under shade, in each fruit sample; fruit color was assessed visually according to the color chart of orange fruit, fruit weight $(\mathrm{g})$, diameter $(\mathrm{cm})$ and length $(\mathrm{cm})$ were measured using a manual vernier caliper. Fruits were peeled; peel and pulp were weighed (g) separately and juice was extracted in a beaker and juice volume $\left(\mathrm{cm}^{3}\right)$ was estimated. A part of the juice was kept in sealed plastic container for biochemical analysis at the spot.

\section{Fruit biochemical analysis}

The fruit juice quality analysis including total soluble solids (TSS), acidity, TSS/acidity ratio and vitamin $\mathrm{C}$ were estimated. The percentage of total soluble solids was measured by hand refractometer. Acidity, as citric acid percentage, was calculated by titration with $0.1 \mathrm{~N}$ sodium hydroxide. Vitamin $\mathrm{C}$ content (mg/100ml juice) was determined by titration with indophenol blue due.

\section{Statistical analysis}

Data collected were subjected to analysis of variance (ANOVA) using the statistical analysis system (SAS, 2003) and the results were considered to be significant at the 0.05 level of probability. Means were separated using the least significance differences (LSD) according to Snedecor and Cochran (1989).

\section{Results}

\section{Fruit Physical analysis}

\section{Fruit weight}

The data presented in Table (1) showed a significant increase in fruit weight compared to the control by spraying calcium chloride and 2,4-D + calcium superphosphate (in the first season), calcium acetate, boric acid, calcium superphosphate and 2,4-D + calcium chloride (in the second season ) and 2,4-D + boric acid and 2,4-D + urea (in both seasons) at the pea stage.

With regard to the marble stage, fruit weight significantly increased in both seasons over the control by spraying boric acid, calcium superphosphate, 2,4-D + calcium chloride, 2,4-D + calcium acetate and 2,4-D + boric acid, with no significant differences among the mentioned treatments were obtained in the second season (Table 1). 
Table 1. Effect of spraying different agricultural chemicals on physical fruit quality of Navel orange trees in 2003 and 2004 season.

\begin{tabular}{|c|c|c|c|c|c|c|c|c|c|c|c|c|}
\hline \multirow{2}{*}{ Treatments } & \multicolumn{2}{|c|}{$\begin{array}{l}\text { Fruit weight } \\
\text { (g) }\end{array}$} & \multicolumn{2}{|c|}{$\begin{array}{l}\text { Fruit length } \\
\text { (cm) }\end{array}$} & \multicolumn{2}{|c|}{$\begin{array}{l}\text { Fruit diameter } \\
\text { (cm) }\end{array}$} & \multicolumn{2}{|c|}{$\begin{array}{l}\text { Fruit length } / \\
\text { diameter ratio }\end{array}$} & \multicolumn{2}{|c|}{$\begin{array}{l}\text { Peel weight } \\
\text { (g) }\end{array}$} & \multicolumn{2}{|c|}{$\begin{array}{l}\text { Pulp weight } \\
\text { (g) }\end{array}$} \\
\hline & $\begin{array}{l}\text { Pea } \\
\text { stage }\end{array}$ & $\begin{array}{l}\text { Marble } \\
\text { stage }\end{array}$ & $\begin{array}{l}\text { Pea } \\
\text { stage }\end{array}$ & $\begin{array}{l}\text { Marble } \\
\text { stage }\end{array}$ & $\begin{array}{l}\text { Pea } \\
\text { stage }\end{array}$ & $\begin{array}{l}\text { Marble } \\
\text { stage }\end{array}$ & $\begin{array}{l}\text { Pea } \\
\text { stage }\end{array}$ & $\begin{array}{l}\text { Marble } \\
\text { stage }\end{array}$ & $\begin{array}{l}\text { Pea } \\
\text { stage }\end{array}$ & $\begin{array}{l}\text { Marble } \\
\text { stage }\end{array}$ & $\begin{array}{l}\text { Pea } \\
\text { stage }\end{array}$ & $\begin{array}{l}\text { Marble } \\
\text { stage }\end{array}$ \\
\hline & & & & & \multicolumn{8}{|c|}{2003 season } \\
\hline$\overline{\mathrm{T} 1}$ & 187 & 187 & 7.16 & 7.12 & 7.04 & 7.22 & 0.99 & 0.98 & 47.9 & 43.80 & 139.5 & 143.5 \\
\hline $\mathrm{T} 2$ & 217 & 209 & 7.42 & 7.33 & 7.26 & 7.55 & 1.01 & 0.96 & 48.9 & 46.70 & 168.8 & 162.6 \\
\hline $\mathrm{T} 3$ & 176 & 245 & 7.00 & 7.64 & 7.09 & 7.86 & 0.98 & 0.96 & 43.5 & 54.85 & 132.5 & 190.9 \\
\hline $\mathrm{T} 4$ & 195 & 217 & 7.07 & 7.42 & 7.08 & 7.62 & 0.99 & 0.96 & 46.6 & 48.25 & 147.7 & 168.7 \\
\hline T5 & 189 & 226 & 7.08 & 7.36 & 7.00 & 7.62 & 1.00 & 0.96 & 41.5 & 45.82 & 147.6 & 180.2 \\
\hline T6 & 193 & 207 & 7.18 & 7.41 & 7.20 & 7.43 & 1.00 & 0.99 & 43.9 & 47.17 & 149.8 & 160.0 \\
\hline $\mathrm{T} 7$ & 207 & 241 & 7.59 & 7.91 & 7.25 & 7.82 & 1.04 & 1.00 & 56.8 & 52.22 & 150.9 & 189.2 \\
\hline T8 & 197 & 203 & 7.26 & 7.30 & 7.07 & 7.48 & 1.02 & 0.97 & 46.3 & 47.77 & 151.4 & 155.3 \\
\hline T9 & 196 & 214 & 7.30 & 7.65 & 7.00 & 7.53 & 1.03 & 1.01 & 46.9 & 46.30 & 149.4 & 168.6 \\
\hline $\mathrm{T} 10$ & 218 & 231 & 7.55 & 7.84 & 7.38 & 7.75 & 1.01 & 1.00 & 49.1 & 51.85 & 169.2 & 179.5 \\
\hline $\mathrm{T} 11$ & 237 & 199 & 7.65 & 7.38 & 7.50 & 7.38 & 1.01 & 0.99 & 49.7 & 44.60 & 183.2 & 154.3 \\
\hline $\mathrm{T} 12$ & 247 & 200 & 7.85 & 7.38 & 7.62 & 7.35 & 1.02 & 0.99 & 36.5 & 47.27 & 205.6 & 153.2 \\
\hline L.S.D $D_{0.05}$ & 26 & 16 & 0.70 & 0.55 & 0.45 & 0.33 & 0.04 & 0.05 & 19.7 & 8.29 & 45.6 & 34.4 \\
\hline \multicolumn{13}{|c|}{2004 season } \\
\hline $\mathrm{T} 1$ & 233 & 221 & 7.82 & 7.61 & 7.57 & 7.52 & 1.04 & 1.00 & 46.2 & 45.87 & 187.5 & 175.0 \\
\hline $\mathrm{T} 2$ & 243 & 245 & 8.07 & 7.92 & 7.65 & 7.85 & 1.05 & 1.02 & 47.4 & 50.05 & 195.5 & 194.7 \\
\hline T3 & 258 & 243 & 8.30 & 7.96 & 7.95 & 7.87 & 1.04 & 1.00 & 55.0 & 50.52 & 203.7 & 193.2 \\
\hline $\mathrm{T} 4$ & 271 & 277 & 8.22 & 7.32 & 7.95 & 8.10 & 1.03 & 1.02 & 46.1 & 54.52 & 217.8 & 222.0 \\
\hline T5 & 243 & 239 & 7.92 & 8.09 & 7.75 & 8.08 & 1.01 & 1.00 & 48.7 & 53.07 & 193.6 & 211.7 \\
\hline T6 & 269 & 266 & 8.22 & 7.99 & 8.12 & 7.99 & 1.01 & 0.99 & 69.0 & 51.77 & 200.6 & 214.5 \\
\hline $\mathrm{T} 7$ & 241 & 243 & 8.10 & 7.86 & 7.62 & 7.84 & 1.03 & 0.99 & 49.4 & 46.65 & 192.2 & 196.5 \\
\hline T8 & 257 & 262 & 8.85 & 8.10 & 7.82 & 7.95 & 0.99 & 1.01 & 49.1 & 58.42 & 208.2 & 204.0 \\
\hline T9 & 250 & 256 & 8.40 & 8.02 & 7.82 & 7.80 & 1.05 & 1.02 & 56.7 & 51.87 & 218.5 & 204.5 \\
\hline $\mathrm{T} 10$ & 256 & 256 & 8.02 & 7.99 & 7.95 & 7.84 & 1.02 & 1.01 & 33.5 & 53.27 & 227.9 & 203.5 \\
\hline $\mathrm{T} 11$ & 277 & 277 & 8.22 & 7.97 & 8.15 & 8.11 & 1.00 & 0.97 & 58.7 & 51.15 & 218.7 & 225.2 \\
\hline T12 & 230 & 262 & 8.00 & 8.21 & 7.57 & 8.02 & 1.05 & 1.01 & 47.9 & 57.25 & 182.1 & 204.7 \\
\hline L.S.D ${ }_{0.05}$ & 22 & 30 & 0.59 & 0.24 & 0.59 & 0.58 & 0.06 & 0.06 & 18.9 & 8.96 & 47.9 & 56.9 \\
\hline
\end{tabular}




\section{Fruit color}

As presented in Table (2), in general an enhancement in fruit color ranged from yellow to yellow -orange was achieved by all sprayed substances at both pea and marble stages, especially, treatments that included foliar spray of 2,4-D.

\section{Fruit biochemical analysis Vitamin C}

With regard to the pea stage, the data of Table (2) showed that vitamin C content was not significantly affected by any of the treatments in both seasons as compared with the control.

Regarding the marble stage, the obtained data showed that foliar sprays of boric acid, urea, 2,4-D, 2,4-D + calcium chloride and 2,4$\mathrm{D}+$ calcium acetate significantly increased vitamin $\mathrm{C}$ content as compared with the control in the first season. In addition, spraying 2,4-D + calcium acetate gave higher vitamin $\mathrm{C}$ content than boric acid, urea and 2,4-D (Table 2).

\section{Acidity}

Spraying 2,4-D + calcium acetate at the pea stage gave significantly lower fruit acidity than the control in the first season. Also, spraying urea and 2,4-D + boric acid at marble stage significantly decreased fruit acidity content in the second season. In contrast, a significant increase in fruit acidity content was obtained in the second season by spraying boric acid at both pea and marble stages as compared to the control. In addition, all other treatments did not significantly affect fruit acidity when sprayed at both pea and marble stages in comparison with the control in both seasons (Table 2).

\section{Total soluble solids}

With regard to the pea stage the data presented in Table (2) showed that fruit total soluble solids (TSS) increased significantly by spraying calcium chloride, 2,4-D, 2,4-D + urea and 2,4-D + calcium superphosphate in both seasons as compared to the control, with no significant differences among them were obtained.
Regarding the marble stage, spraying 2,4D alone and 2,4-D + calcium acetate resulted in higher TSS content than the control in both seasons, with no significant difference obtained between both treatments (Table 2).

\section{TSS/acid ratio}

The data presented in Table (2) showed that in general, all sprayed substances caused an increase in the value of TSS/acid ratio over the control at the pea stage but the differences were not significant except spraying calcium superphosphate, 2,4-D + calcium chloride and 2,4-D + calcium acetate in the first season and calcium acetate in the second season.

Regarding the marble stage, the TSS/acid ratio was significantly increased over the control by spraying 2,4-D and 2,4-D + calcium acetate in the first season and, urea and 2,4-D + boric acid in the second season.

\section{Discussion}

Similar enhancement in fruit physical and biochemical characteristics obtained in the present study by the different sprayed substances specially fruit weight and size, and peel weight is also reported (Agusti et al., 1994; Alberigo, 2002; El-Otmani et al., 2002; Harty et al., 2004). Marzouk and Kassem (2002) reported an increase in fruit length/diameter ratio in Washington Navel orange trees by spraying 2,4-D, in both pea and marble stages and calcium chloride at the marble stage only. Qin XuanNan (1996) reported that spraying orange trees with H3BO3 increased TSS/acidity ratio. On the other hand, Marzouk and Kassem (2002) reported that spraying Washington Navel orange trees with calcium chloride, calcium acetate, urea and 2,4-D, at pea and marble stages, did not affect TSS/acid ratio. The foliar sprays of phosphoric acid recorded the highest value of TSS, total sugars, reducing sugars and carotene contents (Kassem et al., 2010). Fruit size and weight can be improved by increasing carbohydrates availability to fruit or by increasing fruit sink strength. 
Table 2. Effect of spraying different agricultural chemicals on chemical fruit quality of Navel orange trees in 2003 and 2004 season.

\begin{tabular}{|c|c|c|c|c|c|c|c|c|c|c|c|c|}
\hline \multirow{2}{*}{ Treatments } & \multicolumn{2}{|c|}{$\begin{array}{l}\text { Juice volume } \\
\left(\mathrm{cm}^{3}\right)\end{array}$} & \multicolumn{2}{|c|}{$\begin{array}{l}\text { V. C content } \\
\text { (mg/100 ml juice) }\end{array}$} & \multicolumn{2}{|l|}{$\begin{array}{l}\text { Acidity } \\
(\%)\end{array}$} & \multicolumn{2}{|c|}{$\begin{array}{l}\text { T.S.S. content } \\
(\%)\end{array}$} & \multicolumn{2}{|c|}{$\begin{array}{l}\text { T.S.S./acidity } \\
\text { ratio }\end{array}$} & \multicolumn{2}{|c|}{ Fruit colour* } \\
\hline & $\begin{array}{l}\text { Pea } \\
\text { stage }\end{array}$ & $\begin{array}{l}\text { Marble } \\
\text { stage }\end{array}$ & $\begin{array}{l}\text { Pea } \\
\text { stage }\end{array}$ & $\begin{array}{l}\text { Marble } \\
\text { stage }\end{array}$ & $\begin{array}{l}\text { Pea } \\
\text { stage }\end{array}$ & $\begin{array}{l}\text { Marble } \\
\text { stage }\end{array}$ & $\begin{array}{l}\text { Pea } \\
\text { stage }\end{array}$ & $\begin{array}{l}\text { Marble } \\
\text { stage }\end{array}$ & $\begin{array}{l}\text { Pea } \\
\text { stage }\end{array}$ & $\begin{array}{l}\text { Marble } \\
\text { stage }\end{array}$ & $\begin{array}{l}\text { Pea } \\
\text { stage }\end{array}$ & $\begin{array}{l}\text { Marble } \\
\text { stage }\end{array}$ \\
\hline & & & & & \multicolumn{8}{|c|}{2003 season } \\
\hline $\mathrm{T} 1$ & 60.0 & 61.5 & 37 & 23 & 1.27 & 1.29 & 11.7 & 11.47 & 9.25 & 8.94 & $\mathrm{~F}$ & $\mathrm{H}$ \\
\hline $\mathrm{T} 2$ & 72.3 & 69.0 & 38 & 24 & 1.14 & 1.22 & 12.2 & 11.90 & 10.86 & 9.48 & $\mathrm{~J}$ & I \\
\hline T3 & 53.0 & 90.0 & 36 & 23 & 1.24 & 1.34 & 11.9 & 11.45 & 9.67 & 8.55 & I & $\mathrm{H}$ \\
\hline $\mathrm{T} 4$ & 71.5 & 70.0 & 41 & 27 & 1.18 & 1.12 & 11.9 & 11.90 & 10.17 & 10.65 & $\mathrm{G}$ & I \\
\hline $\mathrm{T} 5$ & 61.8 & 76.7 & 36 & 26 & 1.30 & 1.20 & 12.2 & 11.90 & 9.64 & 10.02 & $\mathrm{I}-\mathrm{H}$ & I \\
\hline T6 & 67.3 & 72.5 & 37 & 24 & 1.11 & 1.41 & 12.4 & 11.55 & 11.16 & 8.16 & $\mathrm{H}$ & $\mathrm{H}$ \\
\hline $\mathrm{T} 7$ & 66.3 & 83.7 & 37 & 27 & 1.21 & 1.13 & 12.4 & 13.00 & 10.28 & 11.50 & $\mathrm{H}$ & $\mathrm{H}$ \\
\hline T8 & 68.8 & 64.0 & 36 & 29 & 1.07 & 1.41 & 11.7 & 11.95 & 11.06 & 8.63 & G & I \\
\hline T9 & 62.0 & 69.7 & 36 & 30 & 1.05 & 1.11 & 12.1 & 12.65 & 11.58 & 11.39 & I & I \\
\hline T10 & 77.0 & 76.7 & 34 & 24 & 1.21 & 1.31 & 11.3 & 11.95 & 9.42 & 9.13 & $\mathrm{~F}$ & $\mathrm{H}$ \\
\hline T11 & 84.8 & 66.7 & 39 & 22 & 1.32 & 1.29 & 12.3 & 11.65 & 9.62 & 9.13 & G & $\mathrm{H}$ \\
\hline T12 & 81.5 & 65.5 & 40 & 23 & 1.18 & 1.26 & 12.2 & 12.65 & 10.40 & 10.12 & I & $\mathrm{H}$ \\
\hline L.S.D 0.05 & 20.8 & 17.3 & 4.6 & 2.9 & 0.22 & 0.20 & 0.42 & 0.77 & 1.72 & 1.90 & & \\
\hline & & & & & \multicolumn{8}{|c|}{2004 season } \\
\hline $\mathrm{T} 1$ & 82.5 & 83.0 & 52 & 40 & 1.40 & 1.64 & 13.5 & 13.35 & 9.68 & 8.41 & $\mathrm{G}$ & $\bar{J}$ \\
\hline $\mathrm{T} 2$ & 77.8 & 82.7 & 53 & 37 & 1.40 & 1.57 & 14.1 & 13.60 & 10.05 & 8.00 & $\mathrm{~J}$ & I \\
\hline T3 & 83.0 & 92.5 & 51 & 42 & 1.17 & 1.89 & 13.4 & 13.55 & 11.49 & 7.16 & $\mathrm{I}-\mathrm{H}$ & $\mathrm{J}$ \\
\hline $\mathrm{T} 4$ & 97.5 & 99.5 & 56 & 39 & 1.72 & 1.91 & 13.3 & 13.55 & 7.82 & 7.58 & $\mathrm{~J}$ & $\mathrm{~J}$ \\
\hline $\mathrm{T} 5$ & 86.0 & 101.0 & 52 & 39 & 1.47 & 1.25 & 13.3 & 13.25 & 9.00 & 10.92 & $\mathrm{H}$ & $\mathrm{J}$ \\
\hline T6 & 87.0 & 104.2 & 45 & 37 & 1.45 & 1.67 & 13.8 & 13.15 & 9.41 & 7.84 & $\mathrm{H}$ & I \\
\hline $\mathrm{T} 7$ & 81.3 & 95.5 & 56 & 24 & 1.42 & 1.52 & 14.2 & 14.00 & 9.97 & 9.22 & $\mathrm{~J}$ & $\mathrm{~J}$ \\
\hline T8 & 90.5 & 91.7 & 50 & 40 & 1.52 & 1.49 & 14.3 & 13.65 & 9.74 & 9.26 & I - J & $\mathrm{J}$ \\
\hline T9 & 89.0 & 88.0 & 50 & 40 & 1.45 & 1.79 & 14.2 & 14.20 & 9.75 & 7.94 & I & $\mathrm{J}$ \\
\hline T10 & 88.5 & 86.0 & 45 & 40 & 1.45 & 1.22 & 13.8 & 13.25 & 9.72 & 11.14 & I & $\mathrm{J}$ \\
\hline $\mathrm{T} 11$ & 94.0 & 100.7 & 55 & 36 & 1.60 & 1.55 & 14.1 & 13.25 & 9.18 & 8.70 & I & $\mathrm{J}$ \\
\hline T12 & 77.8 & 87.0 & 56 & 39 & 1.47 & 1.71 & 14.2 & 13.60 & 9.71 & 7.90 & $\mathrm{~J}$ & $\mathrm{~J}$ \\
\hline L.S.D ${ }_{0.05}$ & 25.0 & 27.8 & 8.6 & 5.7 & 0.26 & 0.27 & 0.59 & 0.51 & 1.36 & 1.96 & & \\
\hline
\end{tabular}


Spraying synthetic auxins such as 2,4-D may act in these two ways specially when applied at the cell enlargement stage leading to enhancing cell expansion and increasing fruit size (Agusti et al., 2002). Similar influence might be obtained by urea sprays as it enhances vegetative growth (Kassem et al., 2010), thus, increases carbohydrates content in the fruits and encourages its growth. Calcium is a critical nutrient for citrus fruit quality and is known to be involved in many fundamental physiological plant processes involving cell walls, membranes and enzyme activity (Xu et al., 2009) which might have a direct effect on fruit growth. Also, an enhancement of fruit color was obtained. 2,4-D plays a role in encouraging fruit color break and enhancing peel color in citrus fruit (Agusti et al., 2002, Saleem et al., 2008). foliar urea applied increased the polyamine content, growth rate, and size of developing citrus fruit, as well as their potential to set (Corona, 1994 and Lovatt ans Jaganath, 1998).

Moreover, an increase in fruit biochemical characteristics by spraying 2,4-D and urea was reported (Babu and Yadav, 2002, Gill et al., 2002; Kotsias, 2004; Saleem et al., 2008). The increase in juice volume by 2,4-D and urea sprays might be explained by their influence in enhancing cell expansion which increases vesicle capacity for juice accumulation (Agusti et al., 2002). A significant increase in orange fruit acidity by boric acid sprays was also reported by Qin XuanNan (1996). Moreover, the results of the present study are in line with those of Kim-YongHo et al. (2004) and Kotsias (2004) who found that calcium sprays increased TSS contents of mandarin and orange fruits. Kassem et al. (2010) reprted that the foliar sprays of phosphoric acid recorded the highest value of TSS, total sugars, reducing sugars and carotene contents. phosphoric acid has a major role in the biosynthesis of nucleic acid, ATP molecules, and acts as co-enzyme for many enzymes (Kassem et al., 2010). Hegab et al. (2003) reportsd that the boron promotes starch transformation into saccharides in plant cells. The urea ifoliar spray ncreased juice content, reduced acidity and increased the maturity index (El- Otmani et al., 2004).

\section{Conclusion}

From the investigations it is clear that with application of different agrochemicals at pea and marble stages, fruit quality can be positively manipulated in Washington Navel orange. The 2,4-D alone or combined with calcium compounds at the early stages of fruit growth (mainly the marble stage) could be useful in improving fruit quality.

\section{References}

Agustí, M., A. Martínez-Fuentes and C. Mesejo. 2002. Citrus fruit quality Physiological basis techniques of improvement. Agrociencia 2:1-16.

Agusti, M., V. Almela, M. Aznar, J. Pons and M. El-Otmani. 1994. The use of 2,4-DP to improve fruit size in citrus. Int. Soc. Citricult. 423-427.

Ahmed, W. 2006. Biophysical studies of stionic combinatios in 'Kinnow' mandarin (Citrus reticulata Blanco). Ph.D. Thesis, University of Agriculture, Faisalabad, Pakistan.

Alberigo, L. G. 2002. Foliar uptake of N-P-K sources and urea biuret tolerance in citrus. Acta Hort. 594:627-633.

Andrews, P. K. 2002. How foliar-applied nutrients affect stresses in perennial fruit plants. Acta Hort. 594:49-55.

Babu, K. D. and D. S. Yadav. 2002. Effect of 2,4-Dichlorophenoxy acetic acid on yield and quality of Khasi mandarin (Citrus reticulate Blanco). South Indian Horticulture, 50 (1-3): 31-35.

Corona, J. C. 1994. Relationship of polyamines to fruit set and growth of the 'Washington' navel orange [Citrus sinensis (L.) Osbeck]. Master Thesis, University of California, Riverside, CA.

El-Otmani, M., A. Ait-Oubahou, C. J. Lovatt, F. El-Hassainate, A. Kaanane. 2004. Effect of gibberellic acid, urea and $\mathrm{KNO}_{3}$ on yield and on composition and nutritional 
quality of clementine mandarin fruit juice. Acta Hort. (ISHS) 632:309-315.

El-Otmani, M., A. Ait. Oubahou, F. Z. Taibi, C. J. Lovatt, M. Tagliavini, M. Toselli, L. Bertschinger, P. Brown, D. Nielsen and M. Thalheimer. 2002. Efficacy of foliar urea as an $\mathrm{N}$ source in sustainable citrus production system. Acta Hort. 594:711617.

F.A.O. 2010. Food and Agriculture Organization of the United Nations.

Gill, P. S, S. N. Singh and A. S. Dhatt. 2002. Fruit quality of Kinnow mandarin in response to foliar application of $\mathrm{K}$ and $\mathrm{N}$ fertilizers. Indian J. Citricult. 1(2):150153.

Harty, A., W. Dooling and A. Litle. 2004. Producing world class Navel oranges in New Zealand Part 1: Fruit size and nutrition research. Orchardist 77(4):35-39.

Hegab, M. Y., A. M. A. Shaaray and A. H. I. Taaya. 2003. Effect of different sources and concentrations of boronon growth, fruit setting, yield and fruit quality of washington navel orange trees. Minia J. of Agric. Res of Develop. 23(1):83-96.

Hofer. 2006. Citrus improvement program (CIP) in Egypt, German Organization for Technical Cooperation (GTZ).

Jaganath, I. and C. J. Lovatt. 1998. Efficacy studies on prebloom canopy applications of boron and/or urea to 'Hass' avocado. Proc. $3^{\text {rd }}$ (1995) World Avocado Congr. $1: 181-184$.

Johnson, R. S., R. Rosecrance, S. Weinbaum, H. Andris and J. Z. Wang. 2001. Can we approach complete dependence on foliarapplied urea nitrogen in an early-maturing peach? J. Amer. Soc. Hort. Sci. 126:364370 .

Kassem, H. A., A. M. El-Kobbia, H. A. Marzouk and M. M. El- Sebaiey. 2010. Effect of foliar sprays on fruit retention, quality and yield of Costata persimmon trees. Emir. J. Food Agric. 2010. 22(4):259-274.
Kim-Yong Ho, Moon Young El and HanSeung Gab. 2004. Effect of calcium Formulae foliar application on the water spot outbreak and fruit quality of Satsuma mandarin in the plastic house. Korean J. of Hort. Sci. Technol. 22(1):50-54.

Kotsias, D. 2004. Influence of Citrus aurantium (L.) and Poncirus trifoliata (L.) Raf. rootstocks and nutrient sprays on granulation of Valencia sweet orange [C. sinensis (L.) Osback] fruits. Europ. J. Hort. Sci. 69(6):244-249.

Marzouk, H. A. and H. A. Kassem. 2002. Yield and productivity of Washington Navel orange trees as influenced by sprays of different chemicals. J. Adv. Agric. Res. $7: 571$.

Modise, D. M., A. S. Likuku, M. Thuma and R. Phut. 2009. The influence of exogenously applied 2,4-dichloro phenoxy acetic acid on fruit drop and quality of navel oranges (Citrus sinensis L.) Afr. J. Biotechnol. 8(10):2131-2137.

National Research Council Canada. 1991. Phenoxy Herbicides - Their Effects on Environmental Quality with Accompanying Scientific Criteria for 2,3,7,8-Tetrachloro dibenzo-p-Dioxin (TCDD). Subcommittee on Pesticides and Related Compounds, NRC Associate Committee on Scientific Criteria for Environmental Quality, Ottawa, Canada.

Qin Xuan Nan. 1996. Foliar spray of B, Zn and $\mathrm{Mg}$ and their effect on fruit production and quality of Jincheng orange (Citrus sinensis). J. Southwest Agric. Univ. 18(1):40-45.

Saleem, A. B., A. U. Malik, M. A. Pervez, A. Sattar Khan and M. Nawaz Khan. 2008. Spring application of growth regulators affects fruit quality of 'blood red' sweet orange. Pak. J. Bot. 40(3):1013-1023.

SAS. 2003. SAS Institute Users Guide. Statistical Analysis System.

Shoeib, M. M. and A. El- Sayed. 2003. Response of "Thompson Seedless" grape vines to the spray of some nutrients and 
citric acid. Minia J. Agric. Res. Dev. 23(4):681-698.

Snedecor, G. W. and W. G. Cochran. 1989. Statistical Methods. $8^{\text {th }}$ Edn., Iowa State University Press, Iowa, USA.

Sterling,T. M. and J. C. Hall. 1997. Mechanism of action of natural auxins and the auxinic herbicides. In: R. M. Roe, J. D. Burton and R. J. Kuhr (Eds.). pp. 111-141. Herbi cide Activity: Toxicology, Biochemistry and Molecular Biology. IOS Press, Amsterdam, The Netherlands.
USDA. 2006. Based on the available human and animal evidence from subchronic, chronic, carcinogenicity, mutagenicity, developmental and reproductive toxicity studies in mice, rats, rabbits and dogs and with consideration of the available epidemiological database, WHO does not regard 2,4-D and its salts and esters as either genotoxic or carcinogenic.

Xu, Tao, Li, Tianlai and Qi, Mingfang. 2009. Calcium Requirement for EthyleneInduced Abscission. J. Plant Nutr. 32(3):351-366. 